\title{
Sustainable intensification of beef production in Colombia-Chances for product differentiation and price premiums
}

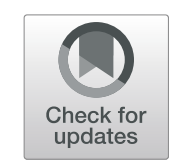

\author{
Andrés Charry ${ }^{1 *}$ D, Manuel Narjes ${ }^{2}$, Karen Enciso ${ }^{1}$, Michael Peters ${ }^{1}$ and Stefan Burkart ${ }^{1}$
}

\footnotetext{
* Correspondence: a.charry@cgiar. org

${ }^{1}$ International Center for Tropical Agriculture, Km 17 Recta Cali Palmira, Valle del Cauca 763537, Colombia

Full list of author information is available at the end of the article
}

\begin{abstract}
To promote the adoption of more sustainable cattle production systems in Colombia (mainly silvopastoral systems with improved forages), some sector stakeholders have proposed the development of differentiated, higher value beef products. However, there have been no rigorous estimations of local market potential and consumer preferences for these hypothetical products yet. On the other hand, while there are clear efforts concerning the environmental impacts of cattle production, its animal welfare implications have taken a secondary place. This research attempts to evaluate the consumer's response to both the environmental and animal welfare aspects of more sustainable food systems by (i) determining the characteristics of a consumer segment for sustainably produced beef using contingent valuation methods and (ii) estimating the marginal willingness to pay (MWTP) for animal welfare compliance and the environmental benefits derived from sustainable intensification within the identified consumer segment, employing a Discrete Choice Experiment (DCE). In addition, the study estimates the effect of information on consumer's MWTP for environmentally friendlier beef. Results show that consumers within the identified segment are willing to pay on average $40.2 \%$ more for beef certified with both animal welfare and eco-friendly standards, with an increase of nearly $10 \%$ after being provided with information of the sector's environmental impacts. These findings support some of the current climate change mitigation strategies in the national cattle industry while highlighting relevant opportunities and trade-offs in the context of a developing country.
\end{abstract}

Keywords: Silvopastoral systems (SPS), Animal welfare, Willingness to pay, Discrete choice experiment (DCE)

\section{Introduction}

The environmental effects of cattle production have gained increasing attention during the last years (Gerber et al. 2015). In Colombia, the sector contributes with nearly $40 \%$ of the greenhouse gas emissions (GHG) and is associated with soil erosion, deforestation, water depletion, and biodiversity losses (Bradford 2015; Interamerican Development Bank [IDB], 2016; Matthews 2006; McAlpine et al. 2009). On the other hand, cattle production is the main economic activity of an important share of the population, with nearly $7 \%$ of the total employment (Lafaurie 2012). In addition, livestock production is in many cases

(c) The Author(s). 2019 Open Access This article is distributed under the terms of the Creative Commons Attribution 4.0 International License (http://creativecommons.org/licenses/by/4.0/), which permits unrestricted use, distribution, and reproduction in any medium, provided you give appropriate credit to the original author(s) and the source, provide a link to the Creative Commons license, and indicate if changes were made. 
one of the few options available to incorporate further marginal lands into productive crop-livestock systems.

Against this background, several strategies have been proposed to mitigate the sector's negative impacts, with some of the most promising initiatives emerging from diet and feed improvement (Gerber et al. 2013). In this sense, major efforts have been conducted globally to promote the sustainable intensification of cattle production systems through (i) the development of superior forages, (ii) the improvement of farming and natural resource management practices, and (iii) the promotion of suitable policies (Ibrahim et al. 2010; Rao et al. 2015).

In Colombia, these technologies have been widely promoted; nevertheless, adoption levels among farmers remain marginal (Rudel et al. 2015) due to lack of knowledge and training, uncertainties on land ownership, low land prices, higher labor requirements and lack of capital, among other factors (Calle et al. 2009; Calle et al. 2013). Sector stakeholders, such as the Colombian Roundtable for Sustainable Beef and Dairy, have proposed the development of differentiated beef products coming from more sustainable production systems (mainly silvopastoral systems [SPS]) as a strategy to up-scale adoption, assuming that higher end product prices will encourage farmers to implement these technological packages (Ruiz et al. 2011), but so far, there have been no rigorous assessments of local consumer response for these products or estimations of potential price premiums.

On the other hand, while there are clear efforts aimed at dealing with the environmental impacts of the sector, animal welfare aspects have taken a secondary place. Currently, regulations and beef production operations include animal welfare elements only to the extent that serves the short-term profit motive (Muñoz-M 2014), without explicitly addressing consumer preferences or the increasing demand for more ethical production systems (Broom 2010).

Different studies have employed stated or revealed preference methods to measure consumer preferences for environmental or ethical improvements in food products and have shown that certain consumer segments are willing to pay more for these attributes. In the case of animal welfare, Clark et al. (2017) conducted a meta-analysis of 54 studies measuring willingness to pay (WTP) for animal welfare aspects, with 24 focusing on beef production, finding that there is an overall small positive WTP (0.63 standard deviations). Other studies focused on organic, free range, or environmentally friendlier meat production find positive price premiums ranging from 8 to 39\%, with large variations related to socio-economic characteristics ( $\mathrm{Li}$ et al. 2016; Curtis et al. 2012; Van Loo et al. 2014). Nevertheless, none of these studies has been conducted in a developing country, particularly in the Latin American context, where the characteristics of both production systems and consumer segments differ substantially from those of developed countries, in spite that they represent more than $27 \%$ of global beef production and a comparable share of consumption (Food and Agriculture Organization of the United Nations [FAOSTAT], 2019; United States Department of Agriculture/ Foreign Agricultural Service, 2019).

Additionally, preference for these attributes has not been measured simultaneously. It is therefore neither clear if consumers experience a greater preference for one of these attributes, nor the extent and form of their perceived interrelationship.

This research attempts to broaden the current body of knowledge by assessing and comparing consumer's preference for both the environmental and animal welfare aspects of 
more sustainable food systems through two approaches: (i) determining the characteristics of beef consumers who would be willing to pay a higher price for more sustainably produced beef and (ii) estimating the marginal willingness to pay (MWTP) for animal welfare standard compliance and the environmental aspects related to the sustainable intensification of the cattle production systems. For this purpose, this research employs a contingent valuation exercise (CV) to understand and determine the characteristics of potential consumers, and a discrete choice experiment (DCE) to estimate the different MWTP for the attributes of interest within the identified consumer segment. In addition, the effect of information on the consumer's MWTP was included in the study.

\section{Sustainable intensification and the livestock sector in Colombia}

Cattle production in Colombia takes place mostly in extensive systems, where animals feed from native and naturalized grasses (Mahecha et al. 2016). Land use is highly inefficient, yet nearly $80 \%$ of the total agricultural land in the country is destined to cattle production (DANE 2014) which translates into high levels of GHG emissions emerging in the form of (i) methane $\left(\mathrm{CH}_{4}\right)$, (ii) released $\mathrm{CO}_{2}$ through land use changes (Wassenaar et al. 2007), and (iii) and nitrous oxide $\left(\mathrm{N}_{2} \mathrm{O}\right)$ derived from manure and fertilizers (Carmona et al. 2005).

In response, stakeholders have been promoting the implementation of silvopastoral systems and improved forages, which can diversify farm income and increase land productivity (Sharrow et al. 2009). In SPS, trees may serve as sources of wood, feed banks, living fences, windbreaks, or provide shadow for the animals (Montagnini et al. 2013), while the improved forages supply larger amounts of biomass per hectare, provide higher nutritional quality, more persistence to biotic and abiotic stresses, and minimize the use of external inputs (Milera 2013; Peters et al. 2001; Rao et al. 2015). Some studies have shown that SPS with improved forages are more profitable than conventional systems that rely on extensive grazing or high fertilization, which translate in lower biomass yield or higher production costs (González, 2013; Turinawe et al. 2012; White et al. 2013). Nevertheless higher implementation costs and relatively long payback periods may be deterring the transition to what appears to be a sound economic decision.

Well-managed SPS mitigate GHG emissions by (1) sequestering atmospheric $\mathrm{CO}_{2}$, (2) by reducing ruminant $\mathrm{CH}_{4}$ emissions per unit livestock product as compared to lower quality forage diets, and (3) by reducing $\mathrm{N}_{2} \mathrm{O}$ emissions (Peters et al. 2013).

While aerial biomass from the trees capture substantial amounts of carbon, wellmanaged improved pastures have shown a larger carbon sequestration potential in the soils (Fisher et al. 2007; Guo \& Gifford 2002; Powers et al. 2011), making them one of the most promising strategies for climate change mitigation in agriculture (Peters et al. 2013; Smith et al. 2008).

$\mathrm{CH}_{4}$ emissions are reduced through gains in feeding efficiency, improved forages are more productive, have higher protein and energy concentration, and show greater resistance to abiotic stresses, allowing for higher loading capacity, higher daily weight gains, and increased food availability during extreme seasons. As found by Gurian-Sherman (2011), improved forages could reduce $\mathrm{CH}_{4}$ emissions by 15 to $30 \%$ through these effects.

Finally, $\mathrm{N}_{2} \mathrm{O}$ emission from the cattle sector is generated mostly from nitrification and denitrification (Bremner and Blackmer 1978) due to the fertilizer use and improper 
manure management. As shown by Sylvester-Bradley et al. (1988) and Subbarao et al. (2009), some tropical forages (Brachiaria spp.) can reduce soil nitrification in a process called biological nitrification inhibition (BNI).

It has been estimated that SPS could be accounted as carbon neutral or even carbon positive through carbon sequestration and gains in feeding efficiency, depending on the variety and density of species introduced (Montagnini et al. 2013; Naranjo et al. 2012). Additionally, SPS contribute to the recovery of degraded lands (Peters et al. 2001), since the plants' root systems promote soil stabilization in sloping areas (Gutteridge and Shelton 1993), improve water holding capacity, soil fertility, and biological activity (Murgueitio et al. 2014).

\section{Animal welfare}

Most of the focus on SPS relate to their environmental or economic effects; nevertheless, these systems can also contribute to improving the animals' life quality by providing shades and reducing heat stress, promoting more stable hierarchies and positive behaviors among heifers, reducing anxiety, and providing more varied, higher quality diets (Améndola et al. 2016; Broom et al. 2013; Panadero 2010). As mentioned earlier, the sector's stakeholders have focused on the effects of animal welfare on productivity, but to the authors' knowledge, no research or sector strategy in the country has yet delved in the ethical aspects of the food industry and its repercussion in consumer choices, even though these aspects have been widely assessed in developed countries and reveal a growing concern for animal welfare (Gwin 2009; Harper and Makatouni 2002; Tonsor et al. 2009).

\section{Materials and methods}

\section{Contingent valuation}

In order to identify the characteristics of a potential consumer for differentiated beef products and obtain information about suitable price premium values for our DCE, a contingent valuation exercise was conducted. Following the structure proposed by Mitchell and Carson (1989), participants were introduced to a hypothetical scenario in which they were buying their most frequently purchased beef cut in their preferred store. Participants were asked if they would be willing to buy the same product with the only differences of having a lower environmental impact (decrease in GHG emissions) and a higher price, along with a brief clarification of the meaning of GHG to reduce information biases. Participants who were willing to purchase were subject to a hypothetical auction, in which the offered price increased at equal intervals of COP \$500 (USD \$0.17) for each affirmative answer until a negative answer was obtained. Finally, they were asked for the exact amount that they were willing to pay within the last price interval.

\section{Hypotheses}

The following hypotheses were tested using the information from the CV:

(1) Consumers of lower income levels have a smaller MWTP for beef with less environmental impact than consumer of higher income levels. 
(2) Sociodemographic characteristics and consumption patterns have a significant effect on the consumers' MWTP for beef with less environmental impact.

\section{Area of study, survey, and sampling}

Primary data collection was conducted between April and May 2016 in the city of Cali, which is located in the Valle del Cauca Department in the southwestern region of Colombia. It is the third largest urban center in the country with more than 2.4 million inhabitants and with an estimated meat consumption between 33 and 42 thousand MT per year (Gonzáles 2015). The city is a major hub for the meat produced in Colombia's northwestern amazon region, which has registered some of the largest rates of forest loss during the past years (González et al., 2018).

A stratified random sampling strategy was employed to select sampling points, using the national socioeconomic stratification system as the stratification variable ${ }^{1}$. Respondents were randomly intercepted within the selected sampling points, and participation in the survey was conditioned to two criteria: (i) the person knows and participates directly in the household's food purchases and (ii) beef is consumed in his/her household. For the selection of sampling points, two sampling frames were constructed. The first included a list of Cali's neighborhoods with predominance of lower strata, from which 12 areas (neighborhoods) were selected using simple random sampling, within which food and meat retailers were selected as the sampling points. Additionally, the two biggest traditional food markets were included due to their economic importance. A second sampling frame was built using a database with information on food and meat retailers located in neighborhoods with predominance of high strata. Ten points were selected from this sampling frame using simple random sampling. The areas selected from both sampling frames were grouped according to geographical proximity producing 14 sampling areas where 168 valid surveys were obtained.

\section{Discrete choice experiment}

Choice experiments are widely used for estimating individuals' MWTP for the ecosystem services of agricultural systems, since they allow determining the marginal value of multiple non-market attributes (Hanley et al. 1998; Lusk and Schroeder, 2004, Makdisi and Marggraf 2011; Meenakshi et al. 2012; Risius and Hamm, 2017; Van Loo et al. 2014).

The premises of choice models establish that given a set of alternatives $j=1,2 \ldots, J$, a rational agent will choose the alternative that delivers the highest utility (McFadden 1974), which may be represented as a decomposition between a systematic (observable) component $V_{i j}$ and a stochastic (unobservable) component $\varepsilon_{i j}$ as follows:

$$
U_{i j}=V_{i j}+\varepsilon_{i j} ; V_{i j}=\beta^{\prime} X_{i j}
$$

where $X_{i j}$ is a vector of observed attributes related to each alternative and individual, and $\beta$ is a vector of parameters that account for the relative contribution of the

\footnotetext{
${ }^{1}$ Socioeconomic stratification in Colombia categorizes housing units in a scale of one to six according to their physical characteristics, immediate surroundings, and rural or urban context. It was implemented for assigning differential public utilities rates to different strata, enabling higher strata (five and six) to pay higher rates and subsidize the costs for lower strata (one, two, and three) (DANE, n.d.)
} 
attribute to the individual's utility. The probability of choosing alternative $k$ can be expressed as:

$$
P_{i k}=P\left(U_{i k}>U_{i j}\right)=P\left[\left(V_{i k}-V_{i j}\right)>\left(\varepsilon_{i j}-\varepsilon_{i k}\right)\right] \forall \mathbf{j} \neq k .
$$

Assuming that the error term follows an extreme value type 1 distribution, the probability to select an alternative can be specified using the general form of the standard logit model (Train 2009). In this research, a mixed logit (ML) model was employed, which is an extension of the standard logit model with less restrictions in its behavioral assumptions, aligning more with a context where individuals experience inter-related perceptions of the alternatives and its components (Hensher et al. 2005; Train 2009). ML models allow for heterogeneity in the estimated parameters by introducing random parameters as follows:

$$
\beta_{i}=\beta+\delta^{\prime} z_{i}+\sigma v_{i}, v_{i} \sim N(0,1)
$$

Here, $\beta$ is the mean value of the parameter, $z_{i}$ is the observed individual characteristics, $v_{i}$ is the individual unobserved heterogeneity, and $\sigma$ is the standard deviation of $\beta_{i}$ around $\beta$ (for this research, the distribution of all parameters estimated is assumed to be normal). The probability of choosing alternative $k$ in ML models is given by the expected value of the standard logit probability over all the possible values of $\beta_{i}$, weighted by the density of $\beta$ as given by,

$$
P_{i k}=\int \frac{\exp \left(\beta^{\prime} X_{k}\right)}{\sum_{j=1}^{J} \exp \left(\beta^{\prime} X_{j}\right)} \phi(\beta \mid \theta) d \beta,
$$

where $\theta$ denotes the moments of the normal density. Provided that at least one attribute is fixed and measured in monetary units, in our case the negative price coefficient $\beta_{p}$, choice models allow for the measurement of MWTP by calculating the ratio

of two parameter estimates $-\frac{\beta_{h}}{\beta_{p}}$, assessing the amount of money an individual is willing to forfeit in exchange for a marginal variation in one of the attributes employed (Hensher et al. 2005).

\section{Experimental design and choice set generation}

The choice sets employed were generated using a random parameter efficient design, which uses prior knowledge to produce estimates with as small as possible standard errors (ChoiceMetrics 2014). Prior parameters were obtained using the results of 180 choices from a pilot conducted with students from the University of Hohenheim, Germany, through an online survey. The choice sets included two beef alternatives and a "no buy" option; the beef alternatives included three attributes, two of which were binary: "meat with 35\% less GHG emissions" and "compliance with animal welfare standards," and a price attribute with four levels. The prior estimates from this pilot were obtained using the NLOGIT4/LIMDEP econometric software.

To adjust the final attribute levels for the Colombian context and for defining the environmental benefits and animal welfare aspects to evaluate, secondary information, local beef prices, and expert guidance were employed. Additionally, focus group discussions were carried out with potential consumers to test and adjust the formulation and 
phrasing of attributes, attribute levels, and the clarity of the information to be presented in the survey. The final attributes and attribute levels are shown in Table 1.

The main effects were defined as labels that certify an "eco-friendly" beef production or "animal welfare" compliance. The eco-friendly attribute was arbitrarily chosen as a design label, i.e., it was assigned an alternative specific constant, while animal welfare was dummy coded. The GHG reduction range conveyed by the eco-friendly label description was rephrased to cover emission reductions of 40 to $100 \%$, relative to beef from a conventional production system (see Appendix 1 for a description of the final attributes provided to the participants).

Irrelevant cases were discarded from the experiment by imposing constraints on the code that generated the underlying design. The final design was generated using the Ngene software and consisted of 14 choice sets, which were presented to the respondents together with a series of visual aids depicting the alternatives (along with an optout option) to facilitate the understanding and execution of the experiment.

\section{Hypotheses}

(1) Beef consumers within the potential consumer segment are willing to pay more for (i) beef with an eco-friendly certification and for (ii) beef with an animal welfare certification.

(2) Beef consumers value eco-friendly certifications and animal welfare certifications differently.

(3) Information on the environmental effects of meat production has a positive effect on the MWTP for beef with an eco-friendly certification.

\section{Survey and sampling}

The experiment was conducted on July 2016 in the city of Cali. Given that the identified consumer segment was characterized by high income and education levels (see the "Results" section), it was determined to limit the survey to individuals living in higher socio-economic strata areas (four to six), which correspond to $15 \%$ of the city's population. Narrowing the characteristics of the target population allowed to reduce variation in perceived product quality standards, beef handling practices, and points of sale characteristics, all of which differ substantially among locations and its corresponding strata. This helped reducing the heterogeneity of uncontrolled hypothetical product perceptions and provided more accurate estimates, which are necessary for differentiated product development, but also narrows the applicability of the results of this stage to consumers within the segment.

Table 1 Experimental design-choice alternatives and levels

\begin{tabular}{lll}
\hline Beef Attributes & Levels & Coding \\
\hline Eco-friendly & No, yes & Alternative specific constant \\
Animal welfare label & No, yes & Binary \\
Prices (in thousand COP//b) ${ }^{\dagger}$ & $9.5,11.5,13.5,15.5$ & Continuous \\
\hline
\end{tabular}

HUSD $1=$ COP $\$ 2879.86$ 
To select sampling points, a sampling frame was built using spatial information of meat and food retailers located in areas of strata four to six. Six sampling points were selected using simple random sampling. Participants were randomly intercepted and the choice sets were randomly presented to avoid ordering bias. Surveyors were trained and fixedword questionnaires were developed in order to keep the length of the experiment to a minimum and to reduce interviewer bias and respondents' fatigue. From this exercise, 171 valid surveys were obtained producing 2394 choices. To measure the effect of information on MWTP, respondents were randomly presented with information about the negative environmental impacts of cattle production (Appendix 2). Significant systematic differences between informed and uninformed participants were ruled out by running $t$ tests on the means of the main sociodemographic characteristics of both groups.

\section{Results}

\section{CV—summary statistics}

Sixty-five percent of the surveyed individuals were women; this overrepresentation might have resulted from limiting participation to people with firsthand information on household food purchases (Table 2). Education ranged from unfinished elementary to postgraduate studies, with an average of 13 years of education, equivalent to completed high school and some higher education. Average monthly per capita income was USD 304.4 , with a high variance (coefficient of variation $=108.2 \%$ ) and a rightly skewed distribution. While the sample contained people from a wide range of income and education levels, there was a lower representation of people from the lower strata and income levels. This bias is most likely related to the selection of sampling points, since some areas of the city were inaccessible due to security issues. Considering these limitations, it was found that $70 \%$ of the participants declared to be willing to pay more for beef with lower environmental impacts, with an average MWTP of USD \$0.34 per lb.

\section{CV-potential consumer characteristics: logit and linear model (Table 2)}

To identify factors that influence consumers' MWTP for a lower environmental impact, two regression models were specified. First, a logit regression using PAYMORE as the

Table 2 Stage $1-C V$ summary statistics

\begin{tabular}{lllllll}
\hline Variable & Description & Obs. & Mean & SD & Min & Max \\
\hline GENDER & 1=female, 0=male & 168 & 0.65 & 0.48 & 0 & 1 \\
AGE & In years & 168 & 46.95 & 15.74 & 18 & 80 \\
EDUC & Average years of schooling & 167 & 13.00 & 3.53 & 3 & 19 \\
STRATA & Household strata (1-6). & 168 & 3.14 & 1.18 & 1 & 6 \\
HHSIZE & Number of people in the household & 167 & 3.32 & 1.65 & 1 & 13 \\
CHILD & 1=children under 12 are living in the household & 168 & 0.30 & 0.46 & 0 & 1 \\
PCINCOME & Monthly per capita income in USD & 167 & 304.4 & 329.3 & 34.0 & 2083.4 \\
PCBEEFEXP & Monthly per capita beef expenditure in USD & 167 & 10.1 & 16.5 & 0.0 & 173.6 \\
FREQBEEF & Frequency of beef consumption in household (times per week) & 167 & 2.57 & 1.38 & 0 & 7 \\
PREFBEEF & 1=respondent prefers beef over other meat alternatives & 168 & 0.31 & 0.46 & 0 & 1 \\
PAYMORE & 1=pays more for beef with less environmental impact & 166 & 0.70 & 0.46 & 0 & 1 \\
HOWMUCH & WTP in USD/lb. of beef & 168 & 0.34 & 0.97 & 0 & 2.43 \\
\hline
\end{tabular}


response variable was conducted (model 1), which allowed to determine the factors that increase the probability that a respondent pays more for the hypothetical product. The second model (model 2) attempted to find factors that influence consumers' MWTP among those who have already declared to pay more. The parameters were estimated using ordinary least squares and employed a log transformation of $\mathrm{HOWMUCH}$ as the dependent variable. The inclusion of variables for both models was determined using a stepwise process per the variables' significance. Robust standard errors were implemented in both models to correct for heteroscedasticity.

As can be observed in Table 3, the chi ${ }^{2}$ test for model 1 allows to ascertain its statistical significance. Although its goodness of fit is poor (pseudo- $R^{2}$ of 0.08 ), model 1 revealed two significant factors for determining preference for "eco-friendly" beef. It can be observed that higher education and a preference for beef over other meat alternatives are the sole significant characteristics differentiating potential and non-potential consumers of "eco-friendly" beef among the socioeconomic information gathered.

Model 2 reveals additional factors influencing the MWTP for differentiated beef among the group of consumers willing to pay a price premium. It can be observed that increases in education level and income increase consumers' MWTP, with income presenting a quadratic relationship. Testing different model specifications and using STRATA as proxy for income also revealed significant effects from STRATA on MWTP, enabling the use of STRATA as a variable for consumer segmentation in stage

Table 3 Models 1 and 2-factors influencing WTP for beef with reduced environmental impact

\begin{tabular}{|c|c|c|c|c|c|}
\hline \multirow{3}{*}{ Variables } & \multirow{3}{*}{ Description } & \multirow{2}{*}{\multicolumn{2}{|c|}{$\begin{array}{l}\text { Model } 1 . \text { Logit } \\
\text { regression } \\
\text { PAYMORE † }\end{array}$}} & \multirow{2}{*}{\multicolumn{2}{|c|}{$\begin{array}{l}\text { Model } 2 \text {. Linear } \\
\text { regression } \\
\text { LOG_HOWMUCH }\end{array}$}} \\
\hline & & & & & \\
\hline & & Coef. & $\begin{array}{l}\text { Robust } \\
\text { SE }\end{array}$ & Coef. & $\begin{array}{l}\text { Robust } \\
\text { SE }\end{array}$ \\
\hline EDUC & Average years of schooling & $0.17^{* * *}$ & 0.062 & $0.036^{* *}$ & 0.016 \\
\hline STRATA & Household strata (1-6). & 0.071 & 0.237 & 0.087 & 0.053 \\
\hline PREFBEEF & $\begin{array}{l}1=\text { respondent prefers beef over other meat } \\
\text { alternatives }\end{array}$ & $-\overline{0.632 *}$ & 0.373 & $-\overline{-}^{-} 324^{* * *}$ & 0.110 \\
\hline AGE & In years & -0.343 & 0.418 & $-0.008^{* *}$ & 0.003 \\
\hline GENDER & $1=$ female, $0=$ male & -0.006 & 0.013 & 0.106 & 0.107 \\
\hline PCINCOME & Monthly per capita income in thousand $\mathrm{COP}^{\S}$ & 0.000 & 0.001 & $0.235^{*}$ & 0.128 \\
\hline PCINCOMESQ & $\begin{array}{l}\text { Monthly per capita income in thousand COP } \\
\text { (squared) }\end{array}$ & 0.000 & 0.000 & $-0.000^{* *}$ & 0.000 \\
\hline CONST. & & -0.540 & 1.110 & $-0.534^{*}$ & 0.280 \\
\hline Observations & & 164 & & 115 & \\
\hline$F(7,107)$ & & & & 8.68 & \\
\hline Prob $>$ F & & & & 0 & \\
\hline$R^{2}$ & & & & 0.250 & \\
\hline Root MSE & & & & 0.558 & \\
\hline Wald $\operatorname{chi}^{2}(7)$ & & 15.61 & & & \\
\hline Prob $>c h i^{2}$ & & 0.029 & & & \\
\hline Pseudo $R^{2}$ & & 0.082 & & & \\
\hline
\end{tabular}

${ }^{* * *} p<0.01,{ }^{* *} p<0.05$ and ${ }^{*} p<0.1$, respectively

${ }^{\dagger} \mathrm{PAYMORE}=1$ if respondent declares to be willing to pay more for beef with reduced environmental impact

${ }^{\ddagger}$ LOG_HOWMUCH = logarithm of declared WTP for beef with reduced environmental impact in thousand COP

§USD $1=$ COP 2879.86 
2. Finally, it can be observed that age and preference for beef over other meat alternatives have a negative effect on consumers' MWTP, decreasing $8 \%$ with a 10 year age increase, and a 32.4\% lower MWTP for "meat lovers." The results from both models revealed two significant determining factors; income and education level, which are relatively easy to distinguish and allow for an initial consumer segmentation.

\section{DCE—summary statistics}

The complete dataset contains 7182 observations corresponding to 14 choice sets, 3 alternatives, and 171 respondents (Table 4). The average monthly income in the sample (USD 638) is substantially higher than the country's monthly minimum wage (USD 239.4) which as required for this stage, corresponds to the characteristics of the potential consumer segment. The sample's respondents were highly educated, with an average of 16.3 years of schooling and over $70 \%$ having completed university or other higher education programs, also fitting the required consumer's profile. Respondents declared assigning on average $13 \%$ of their food expenditure on beef for home consumption, and 35\% of the participants declared preferring beef over other meat alternatives. On average, they consume beef at home 2.8 times per week and $52.8 \mathrm{lbs}$. per person/year, a substantially higher amount compared to the city's average of 31 lbs (Gonzáles, 2015).

\section{DCE-mixed logit model}

Model specification was done through stepwise backward elimination based on variable significance. The resulting model is comprised of three utility functions that represent i) the utility for buying eco-friendly-labeled beef, (ii) conventional beef, and (iii) a "no buy" alternative. The two specifications eco-friendly and no buy included alternativespecific constants making conventional beef the reference alternative. To measure the effect of choosing to buy beef with both certificates, alternative-specific coefficients for

Table 4 Stage 2-DCE summary statistics

\begin{tabular}{lllllll}
\hline Variable & Description & Obs. & mean & SD & Min & Max \\
\hline GEN & 1=female, 0=male & 171 & 0.50 & 0.50 & 0 & 1 \\
AGE & In years & 171 & 43.54 & 15.50 & 17 & 86 \\
STRATA & Household strata (1-6) & 170 & 4.53 & 0.81 & 3 & 6 \\
HHSIZE & Number of people in the household & 171 & 2.95 & 1.18 & 1 & 8 \\
EDUC & Average years of schooling & 171 & 16.29 & 2.17 & 9 & 22 \\
HHINCOME & Monthly household income in USD & 171 & 638.1 & 403.3 & 128.1 & 2855.7 \\
CHILD & 1=children under 12 are living in the household & 171 & 0.37 & 0.48 & 0 & 1 \\
RESTAURANT & 1=respondent's household consumes more beef & 171 & 0.49 & 0.49 & 0 & 1 \\
& out of home & 171 & 3.01 & 3.14 & 0.5 & 28 \\
FREQBUY & Monthly beef purchasing occasions & 167 & 3.32 & 0.67 & 2.08 & 5.79 \\
AVGPRICE & Average price paid per lb. of beef in USD & 171 & 2.80 & 1.71 & 0.25 & 7 \\
FREQCONS & Household beef consumption frequency (times per week) & 171 & 0.35 & 0.48 & 0 & 1 \\
PREFBEEF & 1=respondent prefers beef over other meat alternatives & 170 & 137.3 & 77.4 & 34.7 & 520.9 \\
PCFOODEX & Monthly per capita food expenditure in USD & 170 & 38.9 & 27.2 & 3.3 & 138.9 \\
HHBEEFEXP & Monthly household beef expenditure (for home & 170 & 4.35 & 3.02 & 0.5 & 20 \\
\hline & consumption) in USD & & & &
\end{tabular}


the animal welfare variable in both the eco-friendly and conventional alternatives were specified. The two estimates were significantly different, with the marginal utility from animal welfare being smaller when presented together with the eco-friendly label in the same product (Table 5). This suggests that the simultaneous presence of animal welfare and eco-friendly attributes may have captured a negative synergy effect, perhaps due to information overload or decreasing marginal utility by stacking up attributes.

The information treatment was incorporated into the model by interacting the main effects with a dummy marking the participants on the information treatment. A significant effect for the eco-friendly and information interaction was found. All main effects were set as random parameters with normal distributions, except for the price parameter, which was artificially set to be non-random to obtain WTP point estimates.

The model's 0.43 pseudo- $R^{2}$ indicates a good model fit (Table 5). As expected, the sign of the price coefficient and the "no buy" constant came out negative, while the signs of the remaining attributes resulted positive. All coefficients are significant at $p$ $<0.01$ ( $p<0.001$ for the most relevant main effects), allowing the estimation of MWTP for each attribute.

Table 5 Results-mixed logit model

\begin{tabular}{|c|c|c|c|}
\hline Variable & Description & Coeff. & St. Err. \\
\hline \multicolumn{4}{|l|}{ Random parameters } \\
\hline ECO & ASC for eco-friendly beef ${ }^{\dagger}$ & $2.566^{* * *}$ & 0.426 \\
\hline ANIM_1 & $\begin{array}{l}1=\text { the alternative has animal welfare } \\
\text { certification, for the eco-friendly alternative }\end{array}$ & $1.891^{* * *}$ & 0.357 \\
\hline ANIM_2 & $\begin{array}{l}1=\text { the alternative has animal welfare } \\
\text { certification, for the conventional alternative }\end{array}$ & $2.753^{* * *}$ & 0.466 \\
\hline NB & ASC for not buying beef ${ }^{\dagger}$ & $-11.074^{* * *}$ & 0.509 \\
\hline \multicolumn{4}{|l|}{ Nonrandom parameters } \\
\hline PRICE & Price of the alternative in thousand $\mathrm{COP}^{\ddagger}$ & $-0.937^{* * *}$ & 0.037 \\
\hline \multicolumn{4}{|l|}{ Heterogeneity in mean } \\
\hline ECO_INF & $\begin{array}{l}\text { Interaction variable for eco-friendly and } \\
\text { information treatment variable }\end{array}$ & $1.094^{* *}$ & 0.414 \\
\hline \multicolumn{4}{|c|}{ Standard deviations of parameter distributions } \\
\hline sdECO & & $2.656^{* * *}$ & 0.333 \\
\hline sdANIM_1 & & $2.869^{* * *}$ & 0.304 \\
\hline sdANIM_2 & & $3.726^{* * *}$ & 0.329 \\
\hline $\mathrm{sdNB}$ & & $2.555^{* * *}$ & 0.249 \\
\hline Observations & & & 2394 \\
\hline Iterations completed & & & 54 \\
\hline Log-L fnen & & & -1482.6 \\
\hline Number of parameters & & & 16 \\
\hline $\mathrm{AIC}$ & & & 1.252 \\
\hline Chi2 & & & 2294.9 \\
\hline Prob $>c h i^{2}$ & & & 0 \\
\hline McFadden pseudo $R^{2}$ & & & 0.4362 \\
\hline Adjusted pseudo $R^{2}$ & & & 0.4344 \\
\hline
\end{tabular}

${ }^{* * *} p<0.01,{ }^{* *} p<0.05$, and ${ }^{*} p<0.1$, respectively

${ }^{\dagger} \mathrm{ASC}=$ alternative specific constant

${ }^{*}$ USD 1 = COP 2879.86 
The estimated standard deviations of the random parameters were also significant at $p<0.001$, suggesting that the coefficients in fact vary among the population. Considering that the distributions were assumed normal for all our main effects, it is possible to obtain the share of consumer population with positive MWTP for each attribute by calculating the positive area of the normal distributions for each alternative using its respective parameters as the distribution moments (Train 2009). This revealed that $83.3 \%$ of the consumers show a positive MWTP for the eco-friendly attribute $(16.7 \%$ would present disutility for this attribute) and $77 \%$ of the consumers for the case of animal welfare, but when both labels were present, $74 \%$ of the consumers placed a positive value to animal welfare, meaning that combining both attributes reduces the marginal utility for animal welfare.

\section{Marginal willingness to pay}

The MWTP mean and heterogeneity point estimates for the attributes were calculated as the ratio of the non-monetary coefficients (and corresponding standard deviations) to the price coefficient (Table 6). Given that dummy variables for the no buy option and for the eco-friendly-labeled beef (i.e., conventional beef is pegged at the zero-utility level as a reference) were specified, the estimated MWTP for a pound of conventional beef (i.e., without labels) corresponds, ceteris paribus, to the absolute value of the MWTP for not buying beef. In other words, a consumer would be willing to pay an average of USD 4.05 to compensate for the disutility of not acquiring a pound of conventional beef. While this value is slightly higher than the market price of the selected beef cut in the city (USD 3.8), the estimate falls within the range of one standard deviation of the coefficient, indicating consistency between the model results and current market prices.

Taking the MWTP for conventional beef as the base value, price premiums were calculated for the different attributes. The attributes ECO and ANIM_2 present price premiums of $23.17 \%$ and $24.86 \%$ relative to conventional beef. Wald test results $(p=0.42)$ revealed that these estimates are not statistically different, which indicates that consumers may place similar values to both attributes when presented separately. Additionally, it can be observed that consumers MWTP for animal welfare decreases 6.09\% when both labels are presented together, while environmental information increased the MWTP for ecofriendly beef by $9.88 \%$. A maximum price premium of $50.12 \%$ would be obtained by adding both labels and information in a single beef alternative, when compared to conventional beef. Nevertheless, this value varies widely among the population as can be observed from the relatively large standard deviation of the attributes.

Table 6 Willingness to pay estimations

\begin{tabular}{llll}
\hline Variable & WTP (USD/lb) & Price premium (\%) & SD (USD/lb) \\
\hline ECO & 0.95 & 23.17 & 0.98 \\
ANIM_1 & 0.70 & 17.07 & 1.06 \\
ANIM_2 & 1.02 & 24.86 & 1.38 \\
INF_ECO & 0.41 & 9.88 & \\
NB & -4.10 & & 0.95 \\
\hline${ }^{+}$USD 1 = COP 2879.86 & & &
\end{tabular}




\section{Discussion}

\section{Contingent valuation and consumer segmentation}

This study investigated consumer characteristics and preferences for eco-friendly and animal welfare-labeled beef in Cali, Colombia. Consistent with similar studies (Clark et al. 2017; Dettmann and Dimitri, 2007; do Paço et al. 2009; Rahman and Haque, 2011; Shabani et al. 2013), the results from this CV revealed that education and income relate to a higher consumer MWTP for eco-friendly beef. On the other hand, this study found that consumers who prefer beef over other meat alternatives show a significantly lower WTP for this product. This could hint at Cali's meat consumers with an affinity for beef ("meat lovers") being less environmentally conscious relative to consumers with a more varied meat diet. This could represent an important barrier for market penetration since the most important consumers are less willing to pay for sustainably produced beef.

No significant effects of other behavioral or sociodemographic characteristics on MWTP foreco-friendly beef were found (such as household size, gender, presence of children in the household, per capita beef consumption). This hints that environmental concerns may no longer be niche issues but instead are becoming social norms in the city, a trend identified by Schwepker Jr and Cornwell (1991) in wealthier countries. In that sense, it was interesting to find that $70 \%$ of the sample stated a willingness to pay for eco-friendly beef across varying levels of income and education, even if the stated price premium was minimum.

Based on these results, a consumer segment of middle-high income and education was selected for conducting focus group discussions and the DCE, since targeted group research is needed for a successful development of innovative food products (Jain and Kaur 2006; Sparke and Menrad 2009), which in turn is the presumed necessary condition to create real incentives to up-scale adoption of the proposed production systems.

The researchers are aware of some of the limitations for conducting the proposed segmentation: other non-sociodemographic characteristics such as attitudes, perceptions, and consumption patterns may be more adequate factors for consumer segmentation (Verbeke 2005) and could provide more accurate segments for differentiated beef products within the city. However, difficulties in identifying and selecting participants for the ensuing phases limited the implementation of this approach in this research. Additionally, the selected market segment may appear narrow. Nevertheless, consumer segments may transcend national boundaries (Yavas et al. 1992), which implies that the identified trends might hold for similar consumer segments in other Latin American or developing countries.

\section{Discrete choice experiment and MWTP}

The DCE results show that within the above described segment, consumers are willing to pay a price premium for beef with ethical and environmental differentiation. The values are similar to those found in other studies for a general population in developed countries (e.g., Curtis et al. 2012; Risius and Hamm 2017; Van Loo et al. 2014). Information in a brief format managed to substantially increase the MWTP for eco-friendly beef, suggesting that increasing consumer awareness can substantially stimulate the local demand for more sustainable products and might widen the consumer base for 
eco-friendly certified beef. Accordingly, consumers within this segment would be willing to pay a $51 \%$ price premium for beef that is certified in both eco-friendly and animal welfare standards, when adding information about the negative impacts of current beef production to the product label. It is important to note that while these estimates provide a sound input for developing pricing strategies, they should be handled with prudence given the large heterogeneity found and the potential for hypothetical bias (Mitani and Flores 2010).

No significant differences were found in WTP between animal welfare and ecofriendly attributes when presented independently, which may indicate that both aspects are currently of similar concern to consumers. Nevertheless, results show a lower WTP for the animal welfare attribute when the eco-friendly certification was already included in the product, revealing that consumers are not willing to pay as much for these attributes when they are being combined. This could indicate that preferences for both aspects are not independent in the consumer mindset and that a decreased marginal utility could be expected when adding additional attributes to the same product. This is consistent with the findings from Risius and Hamm (2017), which concluded that products should avoid overwhelming consumers with multiple label schemes.

It is important to highlight that the label description for animal welfare was fully based on current regulations. In that sense, price premiums for animal welfare certified products could be obtained by raising awareness among consumers about the official cattle handling practices, and especially by guaranteeing compliance with the norm through the establishment of reliable control mechanisms, without the need to include stricter practices or regulations.

\section{Conclusions}

As GHG emissions, deforestation, and land degradation increases, so does the need of introducing more sustainable cattle production systems. Given Colombia's current transition to a post-conflict period, more land is expected to be turned into agriculture in the following years and additional incentives for sustainable intensification in these areas can facilitate the sector's transformation. While market-based incentives are not sufficient to achieve the expected systemic changes, they can support the transformation process as long as the primary producers capture a share of the monetary gains.

This study revealed a potential segment for differentiated beef products derived from more sustainable production systems and quantified possible price premiums for such products. While income and education were determinants for purchasing eco-friendly beef, a large share of consumers expressed some willingness to buy eco-friendlier products, which signals the potential for evaluating various strategies for segments with different degrees of purchasing power.

While climate change and GHG emissions remain central among the government and sector stakeholders, the study revealed that consumers place a similar value to ecofriendly and animal welfare compliant production. Additionally, results show that, even brief, consumer information can have high returns on investment given the positive response within the segment. Therefore, decision makers can benefit from simple labeling and communication strategies that clearly combine environmental and animal welfare aspects to contribute in the up-scaling of these technologies. 
On the other hand, while an implementation of SPS provides improvements in both dimensions compared to the conventional or traditional production systems (Améndola et al. 2015; Murgueitio et al. 2014), it does not necessarily imply compliance with animal welfare standards or net emission reductions. Additionally, trade-offs exist since the increasing availability and affordability of intensification technologies may increase the opportunity costs of marginal lands, adding pressure to the agricultural frontier. In this sense, demand stimulation combined with more productive systems could pose environmental risks if not accompanied with an adequate policy framework, command and control mechanisms, and market strategies which include zero deforestation, conservation, or restoration safeguards. In that sense, further research is required to evaluate and determine suitable SPS in different regions and their corresponding environmental effects to analyze the financial and environmental trade-offs.

To the author's knowledge, this is the first DCE study in the region that evaluated consumer preferences for both animal welfare and environmental issues in beef production. The results thus provide a valuable contribution to the literature and for decision makers in the cattle sector by bringing evidence on the national consumer response on both aspects into the current discussion.

The WTP findings from this research are focused on a population segment of a particular city in Colombia (Cali), but could be used as a first approach for markets of animal products with similar contexts in other developing countries. Nevertheless, further research is needed to understand the requirements and consumption patterns of these potential markets and evaluate the consistency of the results across cultures.

Finally, while the participants of the focus group discussions acknowledged the use of "green labels" as an effective strategy to convey the claims of eco-friendly and animal welfare practices in cattle production systems, it is important to highlight that given the proliferation of labels in the food market, issues have emerged in terms of trust, reliability, and independence (United Nations Office for Project Services 2009). To determine the suitability of labels in the Colombian beef market, further research is needed, especially with regard to the effectiveness of market and alternative mechanisms to create, capture, and distribute value in more sustainable value chains.

\section{Appendix 1}

Description of attributes in DCE

Eco-friendly label: This meat was produced in a system that reduces GHG emissions from 40 to $100 \%$ as compared to meat produced in a conventional system. This system also promotes soil recovery by improving its quality and structure.

Animal welfare label: The cattle used for producing this meat was raised, transported, and sacrificed in systems that avoid pain, stress, and fear. Although the absence of this certification does not imply that the animal has been subject to unnecessary suffering, there is no entity guaranteeing the production of this meat by these principles.

\section{Appendix 2}

Information treatment-environmental impacts of the cattle sector.

Cattle production contributes with nearly $9.5 \%$ of total GHG emissions around the globe (those attributed to global warming and climate change), a similar value to that of all transport systems combined, which account for nearly $15 \%$ of total GHG emissions. 
GHG emissions from cattle production are mainly a result of the animal's digestive processes; nevertheless, there are other sources of emissions such as:

- Deforestation to extend grazing areas

- Mismanagement of animal residues

- Fertilizer use to produce cattle fodder

Additionally, excessive grazing has led to a severe soil degradation and aggravated soil erosion in several regions in the country.

\section{Acknowledgements}

We gratefully acknowledge the financial support of the BMZ/GIZ, the Advisory Service on Agricultural Research for Development (BEAF), and the Colombian General Royalties System (SGR). This research was the result of the collaboration of the International Center for Tropical Agriculture (CIAT) and the research group for animal nutrition (NUTRIFACA) of the University of Cauca led by Dr. Nelson Vivas. We thank Dr. Augusto Rodriguez and the Marketing Research group of the University of Valle for their collaboration with the focus group discussions. We would also like to thank the cattle producer associations ASOGAMER and COAGROUSUARIOS for their collaboration in this project.

\section{Authors' contributions}

AC carried out the experiment, analyzed the data, and wrote the manuscript with support from all other authors. MN contributed to the experimental design of DCE, econometric modeling, and related literature review, interpretation, and discussion of results. KE supported in carrying out the experiment, contributed to planning and execution of the field work, and aided in the interpretation of the results. MP supported in technical backstopping for livestock-based systems in LAC, in revision and editing of the article, and in context discussion and conclusion chapters. SB supported in the study design and scope of the article, supervised the project, and strongly supported in field work logistics, revision, and editing of the article. All authors provided critical feedback, discussed the results, and commented on the manuscript. All authors read and approved the final manuscript.

\section{Funding}

This research received no specific grant from any funding agency in the public, commercial, or not-for-profit sectors.

\section{Availability of data and materials}

The datasets used and/or analyzed during the current study are available from the corresponding author on reasonable request.

\section{Competing interests}

The authors declare that they have no competing interests.

\section{Author details}

${ }^{1}$ International Center for Tropical Agriculture, Km 17 Recta Cali Palmira, Valle del Cauca 763537, Colombia. ${ }^{2}$ University of Hohenheim, Schloß Hohenheim 1, 70599 Stuttgart, Germany.

Received: 25 October 2018 Accepted: 15 November 2019

Published online: 12 December 2019

\section{References}

Améndola L, Solorio FJ, Ku-Vera JC, Améndola-Massiotti RD, Zarza H, Galindo F (2016) Social behavior of cattle in tropical silvopastoral and monoculture systems. J Animal 10(05):863-867. https://doi.org/10.1017/\$1751731115002475

Bradford A (2015) Deforestation: facts, causes \& effects. In: Live Science. http://www.livescience.com/27692-deforestation.html. Accessed June 2016.

Bremner JM, Blackmer AM (1978) Nitrous oxide: emission from soils during nitrification of fertilizer nitrogen. J Science. 199(4326):295-296. https://doi.org/10.1126/science.199.4326.295

Broom DM (2010) Animal welfare: an aspect of care, sustainability, and food quality required by the public. J Journal of Veterinary Medical Education. 37(1):83-88. https://doi.org/10.3138/jvme.37.1.83

Broom DM, Galindo FA and Murgueitio E (2013) Sustainable, efficient livestock production with high biodiversity and good welfare for animals. J Proc. R. Soc. 280(1771): 2013-2025. The Royal Society. DOI: https://doi.org/10.1098/rspb.2013.2025

Calle A, Montagnini F, Zuluaga AF (2009) Farmers' perceptions of silvopastoral system promotion in Quindío, Colombia. J Bois et forets des tropiques 300(2):79-94

Calle Z, Murgueitio E, Chará J, Molina CH, Zuluaga AF, Calle A (2013) A strategy for scaling-up Intensive Silvopastoral Systems in Colombia. J Journal of sustainable forestry 32(7):677-693. https://doi.org/10.1080/10549811.2013.817338

Carmona, J. C., Bolívar, D. M., \& Giraldo, L. A. (2005). El gas metano en la producción ganadera y alternativas para medir sus emisiones y aminorar su impacto a nivel ambiental y productivo. Revista Colombiana de Ciencias Pecuarias 18(1):49-63.

ChoiceMetrics (2014) Ngene 1.1.2 User Manual \& Reference Guide, p 248.

Clark B, Stewart GB, Panzone LA, Kyriazakis I, Frewer LJ (2017). Citizens, consumers and farm animal welfare: A meta-analysis of willingness-to-pay studies. Food Policy. 68:112-127.

Curtis K, Feuz S and Aybar N (2012) Consumer willingness to pay for specialty meats. J All Current Publications. Paper 1016. https://digitalcommons.usu.edu/extension_curall/1016 
DANE (2014) Censo Nacional Agropecuario, Tomo 2 Resultados [National Agricultural and Livestock Census, Book 2 Results]. https://www.dane.gov.co. Accessed May 2016

DANE (n.d.) Estratificación socioeconómica para servicios públicos domiciliarios [Socioeconomic stratification for public utilities]. https://www.dane.gov.co.

Dettmann RL and Dimitri C (2007) Organic consumers: a demographic portrayal of organic vegetable consumption within the United States. Paper presented at EAAE International Marketing and International Trade of Quality Food Products Meeting. Bologna, Italy March 2007. Accessed https://EconPapers.repec.org/RePEc:ags:eaa105:7899

do Paço AMF, Raposo MLB, Leal Filho W (2009) Identifying the green consumer: a segmentation study. J Journal of Targeting, Measurement and Analysis for Marketing. 17(1):17-25. https://doi.org/10.1057/jt.2008.28

Fisher MJ, Braz SP, Dos Santos RSM, Urquiaga S, Alves BJR, Boddey RM (2007) Another dimension to grazing systems: soil carbon. J Tropical Grasslands 41(2):65

Food and Agriculture Organization of the United Nations [FAOSTAT] (2019) FAOSTAT Database. Rome, Italy: FAO. http://www. fao.org/faostat/en/\#home Accessed April 2019

Gerber PJ, Mottet A, Opio Cl, Falcucci A, Teillard F (2015) Environmental impacts of beef production: review of challenges and perspectives for durability. J Meat science. 109:2-12. https://doi.org/10.1016/j.meatsci.2015.05.013

Gerber PJ, Steinfeld H, Henderson B, Mottet A, Opio C, Dijkman J, and Tempio G (2013) Tackling climate change through livestock: a global assessment of emissions and mitigation opportunities. Food and Agriculture Organization of the United Nations (FAO).

Gonzáles G (2015) ¿Cuántos embutidos y carnes rojas consumen los caleños? [How much red and processed meat do Cali people eat]. El Pais. http://www.elpais.com.co/elpais/cali/noticias/cuantos-embutidos-y-carnes-rojas-consumen-calenos. Accessed August 2016

González J, Cubillos A, Chadid M, Cubillos A, Arias M... and Berrío V (2018) Caracterización de las principales causas y agentes de la deforestación a nivel nacional período 2005-2015. Instituto de Hidrología, Meteorología y Estudios Ambientales - IDEAM. Ministerio de Ambiente y Desarrollo Sostenible. Programa ONU-REDD Colombia. Bogotá.

González JM (2013) Costos y beneficios de un sistema silvopastoril intensivo (SSPi), con base en Leucaena leucocephala (Estudio de caso en el municipio de Tepalcatepec, Michoacán, México). J Avances en Investigación Agropecuaria 17(3)

Guo LB, Gifford RM (2002) Soil carbon stocks and land use change: a meta analysis. J Global change biology. 8(4):345-360. https://doi.org/10.1046/j.1354-1013.2002.00486.x

Gurian-Sherman D (2011) Raising the steaks: global warming and pasture-raised beef production in the United States. Union of Concerned Scientists, Cambridge, MA

Gutteridge RC, Shelton HM (1993) The scope and potential of tree legumes in agroforestry. J Agroforestry Systems. 23(2-3): 177-194. https://doi.org/10.1007/BF00704914

Gwin L (2009) Scaling-up sustainable livestock production: innovation and challenges for grass-fed beef in the US. J Journal of Sustainable Agriculture. 33(2):189-209

Hanley N, MacMillan D, Wright RE, Bullock C, Simpson I, Parsisson D, Crabtree B (1998) Contingent valuation versus choice experiments: estimating the benefits of environmentally sensitive areas in Scotland. J Journal of agricultural economics. 49(1):1-15. https://doi.org/10.1111/j.1477-9552.2000.tb01214.x

Harper GC and Makatouni A (2002) Consumer perception of organic food production and farm animal welfare. J British Food Journal. 104(3/4/5):287-299. DOl: https://doi.org/10.1108/00070700210425723

Hensher DA, Rose JM, Greene WH (2005) Applied choice analysis: a primer. Cambridge University Press

Ibrahim M, Guerra L, Casasola F and Neely C (2010) Importance of silvopastoral systems for mitigation of climate change and harnessing of environmental benefits. J Grassland carbon sequestration: management, policy and economics. 11:189.

Interamerican Development Bank [IDB] (2016) Agrimonitor. Climate change http://agrimonitor.iadb.org/en/special-topics/ climate-change. Accessed August 2016

Jain SK, Kaur G (2006) Role of socio-demographics in segmenting and profiling green consumers: an exploratory study of consumers in India. J Journal of International Consumer Marketing 18(3):107-146

Lafaurie JF (2012) Retos de la globalización en el mercado lácteo [Challenges of globalization in the dairy market]. FEDEGANFNG. https://goo.gl/3y6lqp. Accessed June 2016

Li X, Jensen KL, Clark CD, Lambert DM (2016) Consumer willingness to pay for beef grown using climate friendly production practices. J Food Policy 64:93-106

Lusk JL, Schroeder TC (2004) Are choice experiments incentive compatible? A test with quality differentiated beef steaks. J American Journal of Agricultural Economics 86(2):467-482. https://doi.org/10.1111/j.0092-5853.2004.00592.x

Mahecha L, Gallego LA, Peláez FJ (2016) Situación actual de la ganadería de carne en Colombia y alternativas para impulsar su competitividad y sostenibilidad. J Revista Colombiana de Ciencias Pecuarias 15(2):213-225

Makdisi F and Marggraf R (2011) Consumer willingness-to-pay for farm animal welfare in Germany-the case of broiler. Paper presented in German Association of Agricultural Economists 51st Annual Conference (pp. 28-30). Halle.

Matthews C (2006) Livestock a Major Threat to Environment. FAO newsroom. Retrieved from https://www.fao.org/newsroom/ en/News/2006/1000448/index.html.

McAlpine CA, Etter A, Fearnside PM, Seabrook L, Laurance WF (2009) Increasing world consumption of beef as a driver of regional and global change: a call for policy action based on evidence from Queensland (Australia), Colombia and Brazil. J Global Environmental Change. 19(1):21-33

McFadden D (1974) Conditional logit analysis of qualitative choice behavior. In: Zarembka P (ed) Frontiers in Econometrics. Academic Press, New York, pp 105-142

Meenakshi JV, Banerji A, Manyong V, Tomlins K, Mittal N, Hamukwala P (2012) Using a discrete choice experiment to elicit the demand for a nutritious food: willingness-to-pay for orange maize in rural Zambia. J Journal of Health Economics 31(1): 62-71. https://doi.org/10.1016/j.jhealeco.2012.01.002

Milera M (2013) Contribución de los sistemas silvopastoriles en la producción y el medio ambiente. J Avances en Investigación Agropecuaria. 17(3):7-24

Mitani Y, Flores N (2010) Hypothetical bias reconsidered: payment and provision uncertainties in a threshold provision mechanism. J Environmental and Resource Economics 59. https://doi.org/10.1007/s10640-013-9741-0

Mitchell RC, Carson RT (1989) Using surveys to value public goods: the contingent valuation method. Resources for the Future, Washington, D.C. 
Montagnini F, Ibrahim M, Murgueitio E (2013) Silvopastoral systems and climate change mitigation in Latin America. J Bois et Forets Des Tropiques. 67(316):3-16

Muñoz-M R (2014) Bienestar animal: un reto en la producción pecuaria [Animal welfare: a challenge in livestock production]. J Spei Domus 10(20):31-40. https://doi.org/10.16925/sp.v10i20.88

Murgueitio E, Chará J, Barahona R, Cuartas C, Naranjo JF (2014) Intensive Silvopastoral Systems (SPS), mitigation and adaptation tool to climate change. J Tropical and Subtropical Agroecosystems 17:49-62

Naranjo JF, Cuartas CA, Murgueitio E, Chará J and Barahona R (2012) Balance de gases de efecto invernadero en sistemas silvopastoriles intensivos con Leucaena leucocephala en Colombia [Greenhouse gas balance in intensive silvopastoral systems with Leucaena leucocephala in Colombia]. Livestock Research for Rural Development. Volume 24, Article \#150. http://www.Irrd.org//rrd24/8/nara24150.htm

Panadero AN (2010) Importancia de los sistemas silvopastoriles en la reducción del estrés calórico en sistemas de producción ganadera tropical. J Revista Medicina Veterinaria (19):113-122. DOI: https://doi.org/10.19052/mv.782

Peters M, Horne P, Schmidt A, Holmann F, Kerridge PC, Tarawali SA, and Fujisaka S (2001) The role of forages in reducing poverty and degradation of natural resources in tropical production systems. Overseas Development Institute (ODI). Agricultural research \& extension network (AgREN).

Peters M, Rao I, Fisher M, Subbarao G, Martens S, Herrero M, and Hyman G (2013) Tropical forage-based systems to mitigate greenhouse gas emissions. In Eco-Efficiency: From Vision to Reality (p. 172-184). http://hdll.handle.net/10568/55611

Powers JS, Corre MD, Twine TE, Veldkamp E (2011) Geographic bias of field observations of soil carbon stocks with tropical land-use changes precludes spatial extrapolation. J Proceedings of the National Academy of Sciences. 108(15):6318-6322. https://doi.org/10.1073/pnas.1016774108

Rahman KM, Haque M (2011) Exploring price sensitivity of a green brand: a consumers' perspective. J World Review of Business Research. 1(2):84-97

Rao I, Peters M, Castro A, Schultze-Kraft R, White D, Fisher M et al (2015) LivestockPlus - the sustainable intensification of forage-based agricultural systems to improve livelihoods and ecosystem services in the tropics. J Tropical Grasslands 3: 59-82. https://doi.org/10.17138/TGFT(3)59-82

Risius A, Hamm U (2017) The effect of information on beef husbandry systems on consumers' preferences and willingness to pay. J Meat Science. 124:9-14. https://doi.org/10.1016/j.meatsci.2016.10.008

Rudel TK, Paul B, White D, Rao IM, Van Der Hoek R, Castro A et al (2015) LivestockPlus: Forages, sustainable intensification, and food security in the tropics. J Ambio. 44(7):685-693. https://doi.org/10.1007/s13280-015-0676-2

Ruiz JP, Murgueitio E, Ibrahim M, Zuluaga AF (2011) Proyecto regional enfoques silvopastoriles integrados para el manejo de ecosistemas (2002-2008) [Regional Project integrated silvopastoral focus for ecosystem management]. Ganadería Colombiana Sostenible, Cali, Fundación CIPAV

Schwepker Jr CH and Cornwell TB (1991) An examination of ecologically concerned consumers and their intention to purchase ecologically packaged products. J Journal of Public Policy \& Marketing. 77-101.

Shabani N, Ashoori M, Taghinejad M, Beyrami H, Fekri MN (2013) The study of green consumers' characteristics and available green sectors in the market. J International Research Journal of Applied and Basic Sciences. 4(7):1880-1883

Sharrow SH, Brauer D, Clason TR, Gene Garrett HE (2009). Silvopastoral practices. North American agroforestry: An integrated science and practice, 2nd edn. American Society of Agronomy, Madison, pp 105-131.

Smith P, Martino D, Cai Z, Gwary D, Janzen H, Kumar P et al (2008) Greenhouse gas mitigation in agriculture. J Philosophical Transactions of the Royal Society B: Biological Sciences. 363(1492):789-813. https://doi.org/10.1098/rstb.2007.2184

Sparke K, Menrad K (2009) Cross-European and functional food-related consumer segmentation for new product development. J Journal of Food Products Marketing 15(3):213-230

Subbarao GV, Nakahara K, Hurtado MDP, Ono H, Moreta DE, Salcedo AF et al (2009) Evidence for biological nitrification inhibition in Brachiaria pastures. J Proceedings of the National Academy of Sciences 106(41):17302-17307. https://doi. org/10.1073/pnas.0903694106

Sylvester-Bradley R, Mosquera D, Mendez JE (1988) Inhibition of nitrate accumulation in tropical grassland soils: effect of nitrogen fertilization and soil disturbance. J Journal of Soil Science. 39(3):407-416. https://doi.org/10.1111/j.1365-2389.1988.tb01226.x

Tonsor GT, Olynk N, Wolf C (2009) Consumer preferences for animal welfare attributes: the case of gestation crates. J Journal of Agricultural and Applied Economics 41(03):713-730. https://doi.org/10.1017/S1074070800003175

Train KE (2009) Discrete choice methods with simulation. A guide to environmental labels - for procurement practitioners of the United Nations System. United Nations for Project Services. Cambridge university press.

Turinawe A, Mugisha J, Kabirizi J (2012) Socio-economic evaluation of improved forage technologies in smallholder dairy cattle farming systems in Uganda. J Journal of agricultural Science 4(3):163

United States Department of Agriculture/Foreign Agricultural Service (2019) Livestock and poultry: world markets and trade. https://www.fas.usda.gov/data/livestock-and-poultry-world-markets-and-trade Accessed April 2019

Van Loo EJ, Caputo V, Nayga RM, Verbeke W (2014) Consumers' valuation of sustainability labels on meat. J Food Policy. 49: 137-150. https://doi.org/10.1016/j.foodpol.2014.07.002

Verbeke W (2005) Consumer acceptance of functional foods: socio-demographic, cognitive and attitudinal determinants. Food quality and preference 16(1):45-57

Wassenaar T, Gerber P, Verburg PH, Rosales M, Ibrahim M, Steinfeld H (2007) Projecting land use changes in the neotropics: the geography of pasture expansion into forest. J Global Environmental Change. 17(1):86-104. https://doi.org/10.1016/j. gloenvcha.2006.03.007

White DS, Peters M, Horne P (2013) Global impacts from improved tropical forages: a meta-analysis revealing overlooked benefits and costs, evolving values and new priorities. J Tropical Grasslands-Forrajes Tropicales 1(1):12-24

Yavas U, Verhage BJ, Green RT (1992) Global consumer segmentation versus local market orientation: empirical findings. J MIR, Management International Review, pp 265-272

\section{Publisher's Note}

Springer Nature remains neutral with regard to jurisdictional claims in published maps and institutional affiliations. 